\title{
There is AlWays More Than LaW! From Low IP Regimes to a Governance Perspective in COPYRIGHT RESEARCH
}

\author{
Christian Katzenbach ${ }^{*}$ \\ Pre-Print, forthcoming in Journal of Technology Law and Policy, Spring 2018
}

\begin{abstract}
Building on the literature on low IP regimes, this paper develops a multimodel governance perspective for copyright research. Qualitative studies have shown that, in both low IP sectors and in heavily regulated sectors, creatives develop their own sets of rules, assumptions and routines that delineate accepted and objectionable practices. While there is empirical evidence, we still lack a theoretical underpinning to understand and investigate these phenomena within a systematic and comparative framework. This paper develops a conceptual framework based on sociological institutionalism (SI). SI provides the theoretical basis for showing that mutually related rights and obligations, and the distinctions between right and wrong, possible and impossible actions are not only constituted by law but also by normative orientations and cognitive framings. This paper suggests a framework with four modes of copyright governance: (1) A regulative dimension, addressing the provision and enforcement of formal rules, laws, court decisions, terms of services; (2) a normative dimension, investigating the prevalent assumptions about legitimate and illegitimate behavior in a specific community or sector; (3) a discursive dimension, addressing the framings and debates on creativity, authorship, and originality; and (4) a technological dimension that investigates the embodiment of affordances and rules in infrastructures, devices, and algorithms relevant to creative work. Thus, when seeking to understand the framing and control of creative practives there is always more than law. These frames may align with legal provisions, but in many cases they do not. The paper applies this framework to existing studies on the governance creative production and dissemination.
\end{abstract}

\footnotetext{
* Senior Researcher, Head of the Research Group Internet Policy and Governance, Alexander von Humboldt Institute for Internet and Society, Berlin, Germany.
} 


\section{TABLE OF CONTENTS}

I. INTRODUCTION ......................................................................... 2

II. Beyond Low IP Regimes: There's always More Than LaW .......... 5

A. Low IP Regimes: IP without Law? ............................................ 5

B. Against the Exceptionalism of Low IP Regimes: There's Always More than Law ...................................................................... 7

III. A Governance Perspective for Empirical Copyright

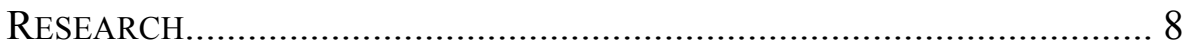

IV. Modes of Copyright Governance: Regulation, Norms, DisCOURSE, TECHNOLOGY .............................................................. 14

A. Regulative Dimension .............................................................. 15

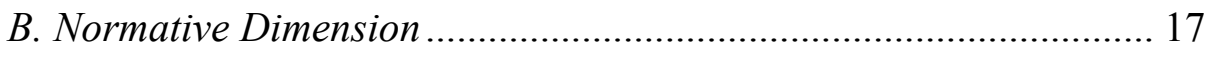

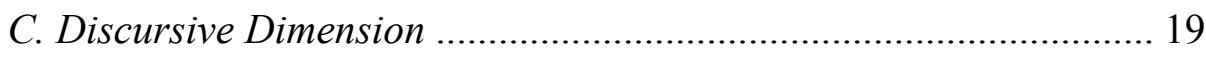

D. Technological Dimension ........................................................... 21

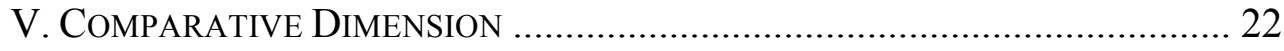

A. Comparing Modes of Governance within a Sector ....................... 22

B. Comparing Modes of Governance across Sectors ........................ 24

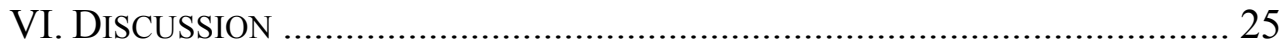

\section{INTRODUCTION}

When creatives talk about their work, they rarely talk about copyright or trademarks. Routines of production, sources of inspiration and collaborations with colleagues and coworkers figure prominently among their narratives of their own work - but not the legal framing. ${ }^{1}$ Yet, the copyright regulation discourse routinely assumes that legal measures are constitutive for creative production: if there is no legal protection for creative works, we assume, creatives will not be able to reap the benefits. In this situation, crea-

1. See, among others, Jessica Silbey, The EurEKA myth: Creators, InNovators, AND EVERyday Intellectual Property (2014) and Laura J. Murray, Tina S. PiPer \& Kirsty Robertson, Putting Intellectual Property in its Place (2014). 
tives would lack incentives to create new works in the first place, with the result that they would not innovate at all.

This great discrepancy between the dominant copyright discourse and creators' own accounts presents a challenge for copyright research. The normative and highly politicized policy debate of the last two decades has paid rather little attention to the concrete practices of cultural production and their commercial exploitation. ${ }^{2}$ But in recent years, research from multiple perspectives has increasingly empirically investigated how copyright unleashes its actual effects in the domains of culture and economy, which socially desirable actions it enables and which it perhaps precludes and exacerbates, and how informal norms and discourses complement legal regulation in ordering creative processes.

In addition to prevailing quantitative approaches and emerging experimental settings, this empirical turn in copyright research has also been driven by qualitative studies that shed light on the practices, routines and norms of creatives and how these relate to legal provisions such as copyright and patents. ${ }^{3}$ Especially the literature on low IP regimes provides instructive insights into the different modalities of organizing and regulating the production and circulation of creative goods. In many case studies, scholars have learned that the absence of formal IP protection does not mean the absence of IP control: Communities such as French chefs, comedians and magicians have developed their own set of rules delineating legitimate and illegitimate practices. ${ }^{4}$

In sum, there is ample empirical evidence supporting the position that when seeking to understand the circulation of creative goods there is

2. See Mark M. A. Lemley, Faith-Based Intellectual Property, 62 UCLA L. Rev. 1328 (2015), and Dan Burk, On the sociology of patenting, 101 Minn. L. Rev., 421-452 (2016) for a recent discussion of this discrepancy. See also Ruth Towse, Creativity, copyright and the creative industries paradigm, 63 KYKLOS, 461 (2010); Christian Handke, Economic effects of copyright (2011); Jeanette Hofmann, Christian Katzenbach \& Merlin Münch, Kulturgütermärkte im Schatten des Urheberrechts, 62 Aus POLITIK UND ZEITGESCHICHTE, 39-45 (2012); R. Towse, The quest for evidence on the economic effects of copyright law, 37 Cambridge Journal of Economics 1187 (2013).

3. Silbey, supra note 1, and Murray, Piper \& Kirstenson, supra note 1.

4. See for paradigmatic case studies Emmanuelle Fauchart \& Eric von Hippel, Norms-Based Intellectual Property Systems: The Case of French Chefs. 19(2) OrGAN. SCI., 187-201 (2008) (on French chefs); Dotan Oliar \& Christopher C. J. Sprigman, There's No Free Laugh (Anymore): The Emergence of Intellectual Property Norms and the Transformation of Stand-Up Comedy, 94 Virginia Law Review 1787 (2008), Jacob Loshin, Secrets Revealed: Protecting Magicians' Intellectual Property Without Law, in LAW AND MAGIC 123, (Christine A. Corcos ed., 2008); and for a recent collection CREATIVITY WithouT Law: Challenging the Assumptions of Intellectual Property (Kate Darling \& Aaron Perzanowski, 2017). 
always more than law involved: These are informal norms, discourses, economic rationales and the technologies underlying creative practices. These frames may align with copyright provisions, but in many cases they do not. ${ }^{5}$ What is still lacking, though, is a theoretical approach to understand and investigate these phenomena within a systematic and comparative framework.

This paper contributes to empirical copyright research by presenting an integrated governance perspective. This conceptual framework seeks to enable the identification and comparison of different modes of ordering and control in creative production and distribution. Based on sociological institutionalism, this governance perspective does not privilege law ex-ante, but positions norms, discourses, and technology as (analytically) equally relevant dimensions of copyright governance.

The reasoning of the paper is presented in three parts: Firstly, I draw on Murray, Piper, and Robertson ${ }^{6}$ to argue against a low IP exceptionalism. The norms and routines ordering creative production in sectors of low IP protection are not unique to these sectors. Instead, they are constitutive of all processes of creative production. Norms and routines are not mere replacements for legal measures in a "negative space of IP". Instead, it is argued here, they are always already present in every form of cultural production and circulation. Thus, the ordering of creative production and circulation is a multimodal process that is realized in many dimensions. This perspective is, secondly, developed into a conceptual framework based on sociological institutionalism (SI) with four modalities of copyright governance: (1) A regulative dimension, addressing the provision and enforcement of formal rules, such as laws, court decisions, terms of services; (2) a normative dimension, investigating the prevalent assumptions about legitimate and illegitimate behavior in a specific community or sector; (3) a discursive dimension, addressing the framings and debates on creativity, authorship, and originality; and (4) a technological dimension that investigates the embodiment of affordances and rules in infrastructures, devices and algorithms relevant to creative work. This will allow us to empirically study the impact and mutual relations of the different modalities across creative sectors. To illustrate this concept, thirdly, the paper discusses the implications of this model for existing case studies on low IP regimes and other sectors.

5. See Silbey, supra note 1, 81-148.

6. Murray, Piper \& Kirstenson, supra note 1.

7. Elizabeth Rosenblatt, $A$ theory of IP's negative space, 34(3) COLUM. J.L. \& ARTS, 317-365 (2011) 


\section{BEYOND LOW IP REgimes: THERE'S AlWAys MORE THAN LAW}

\section{A. Low IP Regimes: IP without Law?}

This investigation into heterogeneous modes of ordering creative production and circulation takes as its starting point the literature on low IP regimes. In empirical studies, scholars are exploring creative practices and products that are hardly amenable to formal IP regulation. Studies on magicians ${ }^{8}$, French chefs ${ }^{9}$, comedians ${ }^{10}$ and roller derby players ${ }^{11}$ have demonstrated that there is more than law in controlling and circulating creative work. In the absence of clear-cut legal protection, these communities have developed norms and routines that delineate acceptable from objectionable practices, thus bringing about "Intellectual Property without law". ${ }^{12}$ The focus on informal regulation in research addressing these seemingly disconnected fields stems from their legal peculiarity: Comedy, magic, and cooking are hardly regulated by formal legal measures. Given this context, stakeholders need to mobilize different modes of regulation other than law in order to coordinate their creative practices and products. In these studies, it is community norms that regulate creative practices and sanction deviant behavior by measures such as exclusion.

By looking at the fashion industry, Raustiala and Sprigman ${ }^{13}$ have given this perspective a slightly different spin: While this sector is highly monetized and subject to a considerate number of formal regulations (trademark, design patents), they are able to show that the sector lacks consistent legal rules for its key creative work: fashion design. ${ }^{14}$ Intellectual property rights are not able to effectively delineate between legitimate inspiration on the one hand and illegitimate plagiarism on the other hand. However, against all assumptions of conventional IP theory, "piracy" does

8. Loshin, supra note 4.

9. Fauchart \& van Hippel, supra note 4.

10. Oliar \& Sprigman, supra note 4.

11. David Fagundes, Talk derby to me: Intellectual property norms governing roller derby pseudonyms, 90 TEX. L. REV. 1093 (2011).

12. Loshin, supra note 4.

13. Kai Raustiala \& Christopher Sprigman, The Privacy Paradox: Innovation and Intellectual Property in Fashion Design, 92 VA. L. REV. 1687 (2006).

14. See Rustiala \&Sprigman, supra note 14, 1699-1705; see also Jessica Litman, The Exclusive Right to Read, 13 Cardozo Arts \& Ent. L.J. 29, 44-45 (1994); Susan Scafidi, Intellectual Property and Fashion Design, in INTELLECTUAL PROPERTY AND INFORMATION Wealth (Yu, ED.) (2006); Christopher Buccafusco \& Jeanne J. C. Fromer, Fashion's Function in Intellectual Property Law, 93 Notre Dame Law Review Forthcoming (2017). 
not lead to market failure here, according to Raustiala and Sprigman, but to a flourishing, innovative industry. ${ }^{15}$

Scholars have addressed a similar puzzle regarding the trade in TV formats. ${ }^{16}$ The legal protection of formats is arguably very weak, yet there is a highly profitable global licensing market for formats. Why do organizations pay to license a format that is not consistently protected? Why develop new formats if you can free ride on existing ones? Standard IP theory "would predict that in the absence of intellectual property protection, the TV show format industry has insufficient incentives to invest in creative innovation". ${ }^{17}$ But producers do invest in new formats. There is not much research on this topic, but empirical studies and economic theory suggest that a mix of business strategies, professional practices and community norms drive the necessary level of innovation in this sector. ${ }^{18}$ Similarly to the fashion industry, imitation as a form of "herding behaviour" rather than innovation hindering it. In a multi-method study on imitation and innovation in game production, we identified similar strategies and professional norms. ${ }^{20}$ Kate Darling has investigated the strategies of the online adult entertainment industry to cope with a low level of copyright enforcement. ${ }^{21}$ Based on qualitative interviews, she has learned that producers shift towards the production of experience goods rather than replicable works. ${ }^{22}$ Consumer privacy preferences, consumption habits, low production costs, and a continuing high demand also help this business to thrive sustainably. ${ }^{23}$

In sum, the literature on low IP regimes supports the position that strong community norms can make up for the lack of formal IP regulation. This perspective has been extended to more commercial, and arguably less community-driven sectors, such as fashion, TV formats, game production, and online adult entertainment. While not constituting clear-cut low IP regimes, creative production in these sectors is not easily protected by formal

15. Raustiala \&Sprigman, supra note $13,1717-1761$.

16. Stefan Bechtold, The fashion of TV show formats, MicH. ST. L. REV., 451- 462 (2013); Martin Kretschmer \& Sukhpreet Singh, Exploiting Idols: A case study of international TV formats trading in the absence of intellectual property protection (2010).

17. Bechtold, supra note 16, at 451.

18. Id.; Kretschmer \& Singh, supra note 16.

19. Bechtold, supra note 16.

20. Christian Katzenbach, Sarah Herweg \& Lies van Roessel, Copies, Clones and Genre Building, InT. J. COMM. 10, 838-859 (2016); Lies van Roessel \& Christian Katzenbach, NAVIGATING THE GREY AREA: GAME PRODUCTION BETWEEN INSPIRATION AND IMITATION [Manuscript currently under review], (2017).

21. Kate Darling, IP without IP? A study of the online adult entertainment industry, STAN. L. REV. 17, 709-771 (2013).

22. Darling, supra note 21, at 765-769.

23. Darling, supra note 21 , at 738-758. 
IP regulation - either because it lacks suitable measures to protect the key creative output (fashion, TV formats, games) or effective enforcement (online adult entertainment). Professionals and companies in these sectors complement this not by strong community norms, but rather by a mix of business strategies, professional norms, and work routines.

\section{B. Against the Exceptionalism of Low IP Regimes: There's Always More than Law}

This strand of research routinely presents low IP regimes as the exceptional case, the "negative space of IP" 24 that represents a puzzle in light of standard theory. Similarly, the strategies in the more complex examples of fashion, TV formats, games, and online adult entertainment are regarded as counter-measures to compensate for a lack of copyright protection and enforcement. Taken together, the literature tends to consider these sectors as instructive, yet exceptional cases. In contrast, most creative sectors are well covered by copyright and other IP regulation, so they do not need informal norms or other complementary strategies, one might argue.

But this position overlooks some constitutive aspects of ordering creative production and circulation: that there is always more than law. Low IP regimes are only exceptional cases with regard to their legal situation. Beyond a "legal centralism", ${ }^{25}$ a broad set of empirical studies and different humanities theories show us that informal norms, discourses, economic rationales, and technologies of production and circulation always contribute to framing and ordering creative practices - whether law provides adequate control or not. As Laura Murray, Tina Piper, and Kirsty Robertson rightly assert, "all creative practices - not merely niches such as magic and standup comedy - feature some sort of embodied ideas about attribution, custodianship, and fair practice. 26

Studies on game design ${ }^{27}$ and a wide range of other creative practic$\mathrm{es}^{28}$ indicate that creators always hold strong concepts of their creative practice and opinions about their relation to their work, sometimes aligning with IP provisions and sometimes not. ${ }^{29}$ In fact, many professionals do not know the applicable copyright regulations, and many rarely encounter or explicit-

24. Rosenblatt, supra note 7.

25. Fagundes, supra note 11, at 1098.

26. Murray, Piper \& Robertson, supra note 1, at 6.

27. See Tom Phillips, "Don't clone my indie game, bro": Informal cultures of videogame regulation in the independent sector, 24 CULTURAL TRENDS 143 (2015); Van Roessel \& Katzenbach, supra note 20, at 10.

28. See Silbey, supra note 5, and Murray, Piper \& Robertson, supra note 1.

29. Silbey, supra note 1, at 81-148. 
ly reflect on legal issues in their working routines. ${ }^{30}$ Fagundes' study on names and branding in roller derby that informal norms emerge regardless of existing formal IP measures. ${ }^{31}$ In her extensive study on creative practices in sectors with mostly strong IP coverage, Jessica Silbey finds strong opinions and informal norms among the interviewees regarding the creative process and the circulation of the creative output. ${ }^{32}$ For different aspects and sectors, Silbey identifies mismatches between the creatives' own positions and formal IP regulation. Especially regarding the creative process itself, the interviews indicate that copyright and patent law is of very little practical importance. Additionally, experimental studies indicate that creative practices are motivated by a wide array of factors, law being one among many. 33

So there is ample empirical evidence for the position that there is always already more than law in ordering creative practices and the circulation of creative works. Informal norms and routines do not only complement law in the absence of formal regulation - but they are always involved. But how do these different mechanisms and dimensions interact? How do they mutually reinforce or undermine each other? How can they be included in a systematic and comparative framework for investigating the ordering of creative practices and the circulation of creative works - without privileging law ex-ante? This paper sets out to contribute to the theoretical advancement of empirical copyright research. In the following, I suggest building blocks for a holistic understanding of the governance of creative practices and the circulation of creative works.

\section{A Governance Perspective for EMPIRICAL COPYRIGHT RE- SEARCH}

The development of a comprehensive framework for analyzing the ordering of creative practices and the circulation of creative outputs can take different approaches with different theoretical underpinnings. One prevalent and instructive approach is transaction cost economics and its variations in economic and institutional theory. Another one addresses motives and incentives on the individual level of creatives and users of creative

30. See Van Roessel \& Christian Katzenbach, supra note 20, at 18.

31. Fagundes, supra note 11.

32. Silbey, supra note 1, at 25-54.

33. Christopher Buccafusco and Christopher Sprigman, Valuing Intellectual Property: An Experiment, 96 CORNELl L. REV. 1 (2010); Christopher Buccafusco et al., Experimental tests of intellectual property laws' creativity thresholds, 93 TEXAS LAW REVIEW 1921 (2014). 
products. Psychologically informed research has provided insight into the reasoning of individuals creating, using and sharing potentially copyrighted works.

This paper, in turn, is grounded in sociological institutionalism. The focus in this perspective is neither on individual motives nor on the calculation of transaction costs, but on the processes of developing and contesting shared norms. Put simply, sociological institutionalism is interested in the ways communities or societies negotiate and establish shared expectations about legitimate and illegitimate practices. For copyright research, and specifically for empirical copyright research this promises to provide a useful theoretical avenue. Building on these concepts will allow scholars to integrate the different mechanisms of ordering at play in creative sectors in a systematic and comparative framework. In contrast to psychological and transaction cost frameworks, this perspective focuses on the meso- and macro-levels of negotiating and contesting norms and understanding. It is thus well positioned to integrate formal regulation on the same level.

Institutions, in this line of theory, are not understood as or restricted to formal organizations or rules. Instead they are, in a broader sense, "building-blocks of social order". ${ }^{34}$ They manifest themselves in different forms such as informal norms, daily routines, organizational procedures, common sayings, but also formal regulations. In essence, institutions "represent socially sanctioned, that is, collectively enforced expectations with respect to the behavior of specific categories of actors or the performance of certain activities. Typically they involve mutually related rights and obligations for actors, distinguishing between appropriate and inappropriate, "right" and "wrong", "possible" and "impossible" 35 actions and thereby organizing behavior into predictable and reliable patterns.

This understanding of institutions focuses on the mutual expectations of social actors and suggests different ways and processes that inform these expectations. The classification of practices as right/wrong, appropriate/inappropriate already anticipates the potential of this sort of institutional theory for the endeavor at hand here: Considering norms, discourses and technology as potentially functional equivalents to copyright regulation, this perspective is agnostic to the different possible modalities of substantiating an institution, i.e. of delineating right/wrong, appropriate/inappropriate law is but one factor.

An important element in this line of institutional theory is its sensitivity to less obvious factors of institutionalization. Prominently, sociolo-

34. Wolfgang Streeck \& KathleEn AnN Thelen, Beyond Continuity: InStituTIONAL CHANGE IN ADVANCED POLITICAL ECONOMIES, 9 (2005).

35. Id. 
gists have stressed the cognitive and discursive dimension of institutions. These dimensions influence behavior not only by normative guidance and by specifying what one should do, but more fundamentally - and maybe even more effectively - by specifying what we imagine that we could do in a given context. ${ }^{36}$ In this perspective, institutions do not primarily consist of "norms and values but [of] taken-for-granted scripts, rules, and classifications". 37

In a recent paper, Dan Burk has analyzed the development and application of patent law from a similar perspective. ${ }^{38}$ Based on sociological institutionalism, he insightfully uncovers the myths and mythology of patent law. His analysis is based on the cognitive dimensions of institutions and thus highlights the prevalent social understandings that bind communities together. Burk argues convincingly that, as narratives that are "true but not factual" 39 , myths contribute to explaining the "puzzle" of the patent law system $^{40}$ that has often been proved ineffective, but remains remarkably stable.

Starting from the same basis, this paper takes a different route in explaining and investigating matters of intellectual property in context. Burk exclusively focuses on the cognitive dimension of institutions. In contrast, this paper follows his call to integrate the other "pillars of institutions". ${ }^{41}$ If succesful, this should facilitate a comparative approach focused on the intersection of and interplay between the different dimensions. In turn, the object of explanation here is more restricted than in Burk's paper. Whereas he delivers a meta-analysis of the consolidation of the patent law system, the framework developed here aims to investigate the classification of actual practices as legitimate/illegitimate with regard to creative works - in other words: this paper addressess the governance of creative practices and products. But both are interested in understanding the role of law in social practices, ${ }^{42}$ thus contributing to a instructive shift in perspective, as Jessica Silbey as pointed out: Instead of imposing ex-ante "the view that intellectual property 'incentivizes' innovation and creativity, and then showing how IP is not working as it should, a social science investigation asks the empir-

36. Lynn G. Zucker, Organizations as Institutions, 2(1) Res. Soc. ORGAN. (1983).

37. Paul J. Dimaggio \& Walter W. Powell, The New Institutionalism in ORGANIZATIONAL ANALYSIS, 15 (1991).

38. Dan Burk, supra note 2.

39. Id., 429.

40. Id., 423.

41. Dan Burk, supra note 2, at 451.

42. Jessica Silbey, Heuristic Interventions in the Study of Intellectual Property, 101 MinN. L. REV. 333, 334 (2016). 
ical question that Burk urges we begin to ask with more determination: '[J]ust what roles [are] patents ... playing?'43

The model for the empirical study of social practices and the role of copyright presented here rests on Richard Scott's typology of institutions, which contain a regulative, a normative and cultural-cognitive pillar. ${ }^{44}$ In his synthesis of institutional theories, he summarizes that institutions are "set in motion by regulative, normative, and cultural-cognitive elements." From this perspective, shared expectations, mutually related rights and obligations, as well as common assumptions about right and wrong, possible and impossible practices are not only constituted by law but also by normative orientations and cognitive framings. As these elements interact, complement and sometimes conflict with each other rather than constituting separate entities, I prefer to call them dimensions instead of pillars. The enduring and coercive impact of institutions then strongly relies on the coherence of these dimensions, as Marie-Laure Djelic and Sigrid Quack explain: "the stability, robustness and self-reproducing characters of institutions will be all the more pronounced that regulative pressures and systems of control combine with normative and cognitive frames and reinforce each other. ${ }^{, 46}$ Conflicts typically arise when informal norms and formal law-or any other dimension - diverge with regard to evaluating right/wrong, appropriate/inappropriate practices.

Turning to copyright, this concept of institutions allows us to develop a multimodal framework to analyze the governance of creative practices and products: It posits that there is (1.) a regulative dimension, addressing the provision and enforcement of formal rules, such as laws, court decisions, contracts, and corporate policies. In short: copyright as usual. But this is only one of many dimensions and not necessarily a privileged one. There is (2.) the normative dimension, describing the prevalent assumptions about legitimate and illegitimate behavior in a specific community or sector (ie. the community norms in the low IP literature). In addition, institutional theory suggests (3.) a cognitive and discursive dimension, addressing the shared (or contested) understandings and framings of issues in certain contexts- An example of the context of copyright relates to the understandings and debates on what constitutes creativity in the first place, the role of orig-

43. Id., 347.

44. Richard W. SCOtT, InStitutions AND ORganizATIONS: IDEAS AND INTERESTS, $51(2008)$.

45. Ib., 49.

46. Marie-Laure Djelic and Sigrid Quack, Theoretical Building Blocks for a Research Agenda Linking Globalization and Institutions, in GLOBALIZATION AND INSTITUTIONS: REDEFINING THE RULES OF THE ECONOMIC GAME 15, 20 (Sigrid Quack ed., 2003). 
inality, or the identification of authorship. While not explicitly present in Scott's model of institutions, it seems reasonable to add (4.) a material or technological dimension that takes into account the affordances and rules embodied in infrastructures, devices, and algorithms relevant to creative work. Scott already concedes that artifacts are important "carriers" for sustaining institutions. ${ }^{47}$ But research in Science and Technology Studies (STS) has shown that technologies and artifacts are more active elements in building and constituting social order. ${ }^{48}$ They do more than just to "embody and represent particular constellations of ideas". ${ }^{49}$ Road bumps, bridges, ${ }^{50}$ automatic door closers, or heavy tags on hotel keys ${ }^{51}$ are the classic examples in this "sociology of things" that illustrate how artifacts have a strong impact on the way we move, talk, and interact. In this sense, technology is an institutionalized form of social interactions or structures that, once institutionalized, has an effect on the social.

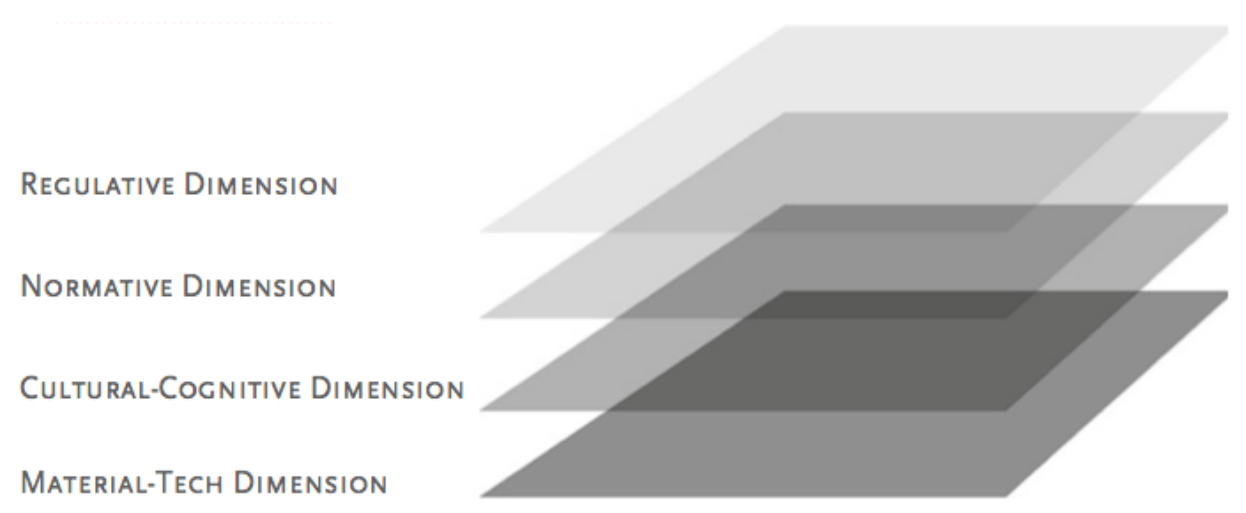

Figure 1: Layers of Institutions

This model diverges from prevalent thinking about copyright regulation in two ways: Firstly, it integrates different modes of ordering into a coherent framework for a empircal research. Thus, it reflects the findings and arguments stemming from the low IP literature that informal norms and shared beliefs are always involved in creative practices - not only in niche sectors. The relation between these dimensions are not set ex-ante by stating

47. Id., 83-85.

48. Bruno Latour, REASSEMBLING THE Social (2008).

49. Scott, supra note 44 , at 85.

50. Langdon Winner, Do Artifacts Have Politics?, 109 Daedalus, 121 (1980).

51. Bruno Latour, Technology is Society made durable, in A Sociology OF MonSTERS 103 (JOHN LAW ED., 1991). 
a putative absence of formal regulation, and norms acting as a surrogate. Instead, they operate on equal footing. The relation between laws, norms, and discourses then is an empirical question that is amenable to research. ${ }^{52}$ Does copyright law prohibit creative practices that are deemed legitimate within a specific context or across an entire society? Are the understandings and routines of creative production in all creative sectors compatible with the categories of copyright (authorship, work, etc.)? Which creative practices do current or past technologies enable and promote and which ones are constrained, not or no longer possible? Does this realm of possibilities align well with informal norms and copyright provisions? In this sense, the legitimacy and robustness of institutions are dependent on the coherence of these dimensions. In sum, this model provides an integrative framework for empirical copyright research that allows us to investigate and compare formal regulations, norms, discourses, and material-technological elements as distinct, yet interdependent modes of copyright governance.

The second feature of this model is that it rests on the notion of governance rather than regulation. While governance as a concept is "notoriously slippery", ${ }^{53}$ it provides analytical value in broadening the concept of regulation. At its core, governance refers to all patterns of rule, and exploring governance means exploring the construction of social order and social coordination ${ }^{54}$ Patterns of rule and ordering mechanisms can take different forms and different trajectories, and thus the notion of governance resonates well with the institutional framework presented here. In contrast, the notion of regulation is characterized by intentional and goal-directed interventions into a policy domain. Julia Black defines regulation as "a process involving the sustained and focused attempt to alter the behavior of others according to identified purposes with the intention of producing a broadly identified outcome." ${ }^{55}$ Regulation may take the form of legislation, private selfregulation or multi-actor arrangements; in all cases, however, it links ordering processes with explicit objectives and measures. Regulatory actors, private or public, assess their options to intervene in a specific field and use the means they deem effective to achieve a desired outcome. ${ }^{56}$ Copyright is

52. And with that, it resonates with Burks call for agnostically trying to understand what IP really does in practice, not assuming an incentive function (or any other) ex-ante, supra note 2, at 452. Similary Silbey, supra note 42, at 347.

53. Jon Pierre \& Guy B. Peters, Governance, Politics And the State, 7 (2008).

54. Mark Bevir, KeY CONCEPTS IN GOVERnANCE, 3 (2009).

55. Julia Black, Decentring Regulation: Understanding the role of regulation and self-regulation in a 'post-regulatory' world, 54(1) CURR. LEG. PROBL., 103-146 (2001).

56. Jeanette Hofmann, Christian Katzenbach \& Kirsten Gollatz, Between Coordination and Regulation: Finding the Governance in Internet Governance, NEW MEDIA \& SoC., $1-18$, at 13 (2016). 
routinely discussed from a regulatory perspective. Which effects do specific provisions have on creative practices or consumption behavior? How can copyright be changed in order to reach desired outcomes? In contrast, the governance perspective put forward here focuses on how certain frames and norms constitute, inform, and question the practices of creatives, as well as users of creative products. This complements the prevalent regulatory perspective in important ways, not only because controlling IP involves more than law - but also because the reference points of our actions are not solely there to guide our creative practices. Shared beliefs, motives, and legitimizations are not here to regulate our practices; they have emerged in longterm processes - and only sometimes they, implicitly or explicitly, inform and guide what we do. In sum, this copyright governance model attributes the ordering and regulation of creative practices to the mutual reinforcement (or weakening) between regulative, normative, discursive, and material elements - some of which are designed to regulate, but many of which are not.

\section{Modes of Copyright Governance: Regulation, Norms, DisCOURSE, TECHNOLOGY}

This section illustrates the analytical and empirical value of the proposed model by spelling out the kind of questions and answers it enables, and by providing a short application of the model to the governance of imitation and innovation in game development. This illustrative case study is based on a multi-method case investigation: A document analysis of industry handbooks, a discourse analysis of contested cases, and extensive interviews with different professionals and stakeholders from the games sector in Germany. We conducted semi-structured interviews with twenty German game practitioners and four legal consultants and in-house lawyers, taking about 90 minutes each.

\begin{tabular}{|c|c|c|c|}
\hline & Research Questions & $\begin{array}{l}\text { Empirical } \\
\text { Account }\end{array}$ & Examples \\
\hline $\begin{array}{l}\text { Regulative } \\
\text { Dimension }\end{array}$ & $\begin{array}{l}\text { Which actors establish } \\
\text { which rules (scope!)? } \\
\text { How is compliance } \\
\text { monitored and deviation } \\
\text { sanctioned? } \\
\text { How are Rules inter- } \\
\text { preted and adapted? }\end{array}$ & $\begin{array}{l}\text { Legal Analysis, } \\
\text { Policy Docu- } \\
\text { ments, } \\
\text { Legislation Pro- } \\
\text { cess }\end{array}$ & $\begin{array}{l}\text { Copyright for } \\
\text { Games, } \\
\text { ND Agreements, } \\
\text { Internal Corporate } \\
\text { Policies, } \\
\text { Terms of Service } \\
\text { of Development }\end{array}$ \\
\hline
\end{tabular}




\begin{tabular}{|c|c|c|c|}
\hline & & & Environments \\
\hline $\begin{array}{l}\text { Normative } \\
\text { Dimension }\end{array}$ & $\begin{array}{l}\text { With which normative } \\
\text { expectations are actors } \\
\text { confronted? } \\
\text { Which expectations are } \\
\text { internalized? } \\
\text { How are these norms } \\
\text { establish and negotiat- } \\
\text { ed? }\end{array}$ & $\begin{array}{l}\text { Interviews, } \\
\text { Ethnographies, } \\
\text { Participatory } \\
\text { Observations }\end{array}$ & $\begin{array}{l}\text { Norms within } \\
\text { Communities, } \\
\text { Comedy, } \\
\text { French Chefs }\end{array}$ \\
\hline $\begin{array}{l}\text { Discursive } \\
\text { Dimension }\end{array}$ & $\begin{array}{l}\text { What is ,taken for } \\
\text { granted“"? } \\
\text { Construction and de- } \\
\text { construction of shared } \\
\text { frames and perspectives }\end{array}$ & $\begin{array}{l}\text { Discourse Anal- } \\
\text { yses, } \\
\text { Politicization, } \\
\text { Issue Formation, } \\
\text { Frames }\end{array}$ & $\begin{array}{l}\text { Debates around } \\
\text { „Piracy“ and } \\
\text { „Stealing“ IP, } \\
\text { Understandings of } \\
\text { Authorship and } \\
\text { Creativity }\end{array}$ \\
\hline $\begin{array}{l}\text { Technolog- } \\
\text { ical Dimen- } \\
\text { sion }\end{array}$ & $\begin{array}{l}\text { Which rules and as- } \\
\text { sumptions are inscribed } \\
\text { into technology? } \\
\text { How do services and } \\
\text { algorithms structure and } \\
\text { regulate our creative } \\
\text { practices and our media } \\
\text { usage? }\end{array}$ & $\begin{array}{l}\text { Analyses of } \\
\text { Technologies, } \\
\text { Ethnographies of } \\
\text { Tinkering, } \\
\text { Digital Methods, } \\
\text { User Interactions }\end{array}$ & $\begin{array}{l}\text { Digital Rights } \\
\text { Management, } \\
\text { YouTube's Up- } \\
\text { load-Filtering } \\
\text { (Content ID), } \\
\text { Development Envi- } \\
\text { ronment }\end{array}$ \\
\hline
\end{tabular}

Table 1: Modes and Lead Questions of Copyright Governance

\section{A. Regulative Dimension}

The regulative dimension is the one that is most familiar to scholars of copyright. In addressing the manifest rules and regulations, it is mainly concerned with laws, contracts, court decisions and other legal documents. As an institutional element, the regulative dimension operates essentially in three steps: rule-setting, monitoring, and enforcement. In this view, institutions are accomplished through "the capacity to establish rules, inspect others' conformity to them, and, as necessary, manipulate sanctions - rewards 
or punishments - in an attempt to influence future behavior., ${ }^{, 57}$ Researching this aspect of governance might be considered business-as-usual for copyright scholarship, hence this paper will not go into much detail here. Investigating this dimension can include both the substance of rules (e.g. legal analysis) as well as its emergence and implementation (e.g. policy analysis).

In the case study, we were interested in understanding how different modes of governance frame and regulate imitation and innovation in game production. The production of games is characterized by the fact that imitation is a common and necessary industry practice that even spurs innovation. Entire game genres (one think of platform side scroller games or first person shooters) have emerged by re-making and extending on great games. ${ }^{58}$ While the view that imitation is a constituent part of innovation seems to be shared throughout the industry. Recent tussles over alleged clones have sparked lively discussions about legitimate and illegitimate imitation practices in game development.

Interestingly, the legal and regulative dimension is far from providing a clear-cut answer for "navigating this grey zone". 59 Games are composed of several elements (rules, graphics, source code, audio), some of which can be separately protected by intellectual property law. For instance, the source code and audiovisual elements are protected by copyright, and game hardware manufacturers often have their technology patented. ${ }^{60}$ However, a unique part of games compared to other audiovisual media is the rule-based system. For example, in the case of chess, it is not the exact colors and shapes of the pieces that define the game, it is the possible moves and affordances of the pieces, the actions that emerge from these affordances and the interplay between the actions. Such rule-based systems could arguably be understood as (abstract) ideas rather than (concrete, fixed) expressions. ${ }^{61}$ As such, games have an "uncopyrightable core: the actual play of the game". ${ }^{62}$ Thus, the long-lasting tension between imitation and inspi-

57. Scott, supra note 44, at 52.

58. JESPER JUUl, A CASUAL REVOLUTION: REINVENTING VIDEO GAMES AND THEIR PLAYERS. (2010).

59. Van Roessel \& Katzenbach, supra note 20.

60. CASEy O'Donnell, DeVEloper's Dilemma: The SeCret World of VideOgame CREATORS (2014); Arya Tayebi, Interactivity, Immersion and Innovation: Can videogames be adequately protected by copyright law? available at: https://aryatayebi.wordpress.com/ 2012/02/10/interactivity-immersion-and-ideas-can-videogames-be-adequately-protectedby-copyright-law/ (2012).

61. Greg Lastowka, Copyright Law and Video Games: A Brief History of an Interactive Medium (2013); Tayebi, supra note 43.

62. Bruce E. Boyden, Games and other uncopyrightable systems, Geo. Mason L. Rev. 18(2), 439-479, at 479 (2011). 
ration in the games sector and the conflicts around the alleged copying of games is not easily resolved in the regulative dimension. ${ }^{63}$

In the interviews we conducted, we were confronted with a striking neglect of the regulative dimension both with regard to the tension between imitation and innovation as well as to legal aspects of game production in general. To put it plainly, the designers, graphic artists and programmers that produce the games we play every day, and that generate enormous revenues, do neither reflect legal issues in their daily work routines nor are there regular interactions with legal staff. They seem to operate with vague lay concepts of copyright in the back of their minds; when asked directly most developers could not assess correctly if a certain game element was protected by copyright or not, or if a certain practice crosses the line to infringement. Only in big studios professional legal assessments are included in the process, but at very late stages when production is mostly done and marketing kicks in. In sum, the regulative dimension is not totally absent from creative processes of game production, but it is certainly in the background.

\section{B. Normative Dimension}

The normative dimension addresses values and norms that classify practices as legitimate/illegitimate and appropriate/inappropriate. In contrast to the regulative dimension, rules here are neither manifest nor are they sanctioned by defined punishments. Instead, they are grounded in shared values and operate as normative expectations: "The expectations are held by other salient actors in the situation, and so are experienced by the focal actor as external pressures. And, to varying degrees, they become internalized by the actor."64 Typically, norms are strongly contextual and differ between communities, societies and world regions. This dimension of governance operates according to a "logic of appropriateness". 65 In this perspective, people do not behave according to an economic calculus nor to a legal assessment, but they adjust their actions to what they perceive as appropriate in a certain situation and context.

63. The assessment of games as objects of copyright and related IP provisions is not key to the argument of this paper, so I keep it short. Cf. Lastowka, supra note 61; Tayebi supra note 60 , and Boyden, supra note 62 , for thorough analyses of copyright's application to digital games and long lists of court cases.

64. Scott, supra note 44, at 55.

65. James G. March \& Johan P. Olsen, Rediscovering Institutions: The ORGANIZATIONAL BASIS OF POLITICS, 23 (1989). 
To act appropriately is to proceed according to the institutionalized practices of a collectivity and mutual understandings of what is true, reasonable, natural, right, and good. Actors seek to fulfill the obligations and duties encapsulated in a role, an identity, and a membership in a political community. Rules are followed because they are perceived to be adequate for the task at hand and to have normative validity. ${ }^{66}$

The literature on low IP regimes is strongly based on this perspective, although sometimes the connection is not always drawn. The community of French chef investigated by Emmanuelle Fauchart and Eric von Hippel displays typical aspects of normative ordering. ${ }^{67}$ Implicit rules and shared expectations about legitimate and illegitimate practices are established, such as a prohibition of 1:1 copies, confidentiality, and referencing the original creator. ${ }^{68}$ Non-compliance to these expectations is not sanctioned by monetary or legal punishments but by exclusion from the community and from further sharing of expertise. ${ }^{69}$ With recipes and original ideas for the combination of ingredients not being protected by formal IP provisions but by these informal norms, the normative dimension and the regulative dimension are not congruent in the case of French haute cuisine.

Our interview study on game production, similarly revealed divergence between these dimensions but with a weaker normative stance and less cohesion within the community. There is consensus between professionals across the industry that "re-skinning" a game, that is plainly copying a game and only changing the art style, is an objectionable practice. Especially if the rule-based system strongly shapes the gameplay experience, copying the system and merely coating it with another visual layer is even more illegitimate. "I think it's okay if you just copy the idea [...] and do your own game, your own balancing, your own pricing. What is harder or, what I think you should not do, or what I don't wanna do myself, is to take a game and copy it exactly, only change the art stuff." This informal norm runs counter the regulative dimension, since copying the game idea and game play does not constitute copyright infringement as long as you reprogram and re-skin the product.

66. Johan P. Olsen, Understanding Institutions and Logics of Appropriateness, 3 (2007).

67. Fauchart \& von Hippel, supra note 4.

68. Id., 193.

69. Id., 195. 
On the other hand, the copyright infringing practice of taking art assets of classic games such as Super Mario is in many cases considered legitimate practice, as long as the game developers add interesting twists to their own game and not merely copy the whole game.

In sum, the normative dimension rests on cohesive communities and societies to establish shared norms and expectations. The evocative cases of the low IP literature are examples of that (French chefs, US comedians, magicians). In the case of the games industry, we found community norms to be less strong. This might be no surprise since the market is huge, global and highly profitable which rather hinders the development of shared norms. Only in the sub-set of so-called Indie Developers strong community norms and beliefs were recognizable.

\section{Discursive Dimension}

The third dimension addressed the ways we understand and talk about creative practices and products. This does not necessarily imply direct normative assessment but nonetheless shapes our thinking and doing. In Scott's institutional theory, this dimension is denoted as the "culturalcognitive pillar" of institutions. In that view, "compliance occurs in many circumstances because other types of behavior are inconceivable; routines are followed because they are taken for granted as "the way we do these things". ${ }^{70}$ In contrast to the regulative and the normative dimension, practices here at not explicitly classified as legitimate//illegitimate. We just take certain things as taken-for-granted and routinely follow these assumptions.

Dan Burk's paper on the sociology of patenting addresses this dimension. ${ }^{71}$ When he refers to Mircea Eliade's definition of myths as narratives that are "true but not factual", ${ }^{72}$ he exactly refers to the enduring quality and impact of widely shared beliefs that are deeply embedded in social routines and structures, so that questioning them is a hard job, even with good reasons.

In this paper, I rename this dimension as discursive dimension, because communication and discourses are the medium in which these beliefs and frames can be identified. With "piracy" and "stealing" on the one hand, and "sharing" on the other hand, the copyright debates are replete with examples for discursive struggles over the ways we should understand and frame the changing practices of media and culture. Whereas most scholarship addresses these debates only as prelude or as independent variable for

70. Scott, supra note 44 , at 58.

71. Burk, supra note 2.

72. Id., 429; Mircea Eliade, Myth AND Reality (1963). 
the real thing: copyright reform and legislation, ${ }^{73}$ an institutional understanding of governance suggests to take the discursive dimension serious in its own right: Words matter!

The brilliant works by Martha Woodmansee ${ }^{74}$ and Mark Rose ${ }^{75}$ on the emergence of the author-concept and its important impact on the consolidation of copyright as a legal instrument point to another aspect of this dimension. The regulative as well as the normative dimension are strongly dependent on the discursive dimension. Here, subjects and categories are constructed, and only on these grounds normative and regulatory provisions can operate. How do we come to privilege the author over the paper factory with regard to a book? Why do we take the idea of a self-contained work for granted, although we know that we all stand on the shoulders of giants? ${ }^{76}$

With regard to our interview study, I highlight three strong currents in this dimension. The first concerns creators' understanding of game design. All game professionals interviewed hold that game production is a highly collaborative process, full of mutual imitation and references. Devising new games, always and necessarily, includes great portions of existing ideas. Indeed, for a new game to become a good game, professionals argue that you should not innovate on all levels of game design; otherwise players would be confused and unable to play the game. Instead, remixing existing elements and giving the game an original twist is considered good game design: "A lot of time it's more about picking the right ingredients that are already there. I mean, $95 \%$ of what we do always [already] exists somewhere." The second aspect concerns game professionals' self-concept as creatives. Almost all interviewees, whether working as independent game developers or as employees in a big studio, considered themselves as creative professionals, thus aiming for producing something new and original in their daily job. This self-concept has ramifications for the tension between imitation and innovation discussed here. Even if the management demands replicas of successful games by competitors, the developers are guided by strong intrinsic motivations to include original elements in the new game.

73. Cf. the excellent work by Sebastian Haunss, Conflicts IN THE KNOwLEdge Society: The CONTENTIOUS Politics OF INTELleCtual Property (2013) and many others.

74. Martha Woodmansee, The Genius and the Copyright: Economic and Legal Conditions of the Emergence of the 'Author'. 17(4) EIGHTEENTH-CENT. STUD., 425-448 (1984).

75. Mark Rose, The Author as Proprietor: Donaldson v. Becket and the Genealogy of Modern Authorship, 23 REPRESENTATIONS, 51-85 (1988).

76. Regulatory theory has somehow included this into its concepts by acknowledging that ,the underlying ideas $[\ldots]$ and the broader intellectual climate that regulatory instruments“ (Robert Baldwin, Martin CAVE \& MARTin Lodge, Understanding RegulaTION, 52 [2012]) - but again only as a prelude to "serious" regulation. 
As one interviewee put it: "I always try to smuggle something in." A third element in this dimension stemming from the interviews is a strong understanding of authorship in a sub-set of the interviewees. Especially, indie developers articulate a strong identification with their work. They consider the developed games as "theirs", as personal expressions. They understand the games they produce not foremost as commercial products but as "heart projects." Some indie developers interviewed classified their games as "Autorenspiele" [author games].

\section{Technological Dimension}

The fourth dimension in this copyright governance model is the material-technological layer. The services and devices we use in our private and professional lives enable and at the same time constrain the range of actions we pursue. From an institutional perspective, they contribute to ordering the social jointly with regulative, normative and discursive elements. As John Law writes: "Machines, architectures, clothes, texts - all contribute to the patterning of the social. ${ }^{677}$ In this dimension, to put it plainly, the distinction between right/wrong, appropriate/inappropriate is translated into possible/impossible.

In the broader field of Internet Governance Joel Reidenberg and Lawrence Lessig have made a similar argument already in the late 1990s:

Law and government regulation are [...] not the only source of rule-making. Technological capabilities and system design choices impose rules on participants [...]; the set of rules for information flows imposed by technology and communication networks form a 'lex informatica'. ${ }^{78}$

For this perspective, Lawrence Lessig (1999) has coined the catch phrase "Code is Law". ${ }^{79}$ That line of argument always runs the risk of falling into the trap of technological determinism, but integrated into an institutional perspective it provides an instructive impulse into our thinking about how creatives work and products are regulated and framed.

77. John Law, Notes on the theory of the actor-network: Ordering, strategy, and heterogeneity, 5 SYSTEMS PRACTICE , 379, 382 (1992).

78. Joel R. Reidenberg, Lex Informatica: The Formation of Information Policy Rules through Technology, 76 TEX. L. REV., 553, 554 (1998).

79. LaWrence Lessig, Code AND Other Laws of CyberspaCe (1999). 
Especially for copyright research, this dimension is of particular importance. Digital Rights Management is an obvious example for the direct delegation of regulatory functions to the technological dimension. These systems try to translate strictly the legal/illegal distinction into possible/impossible actions on our devices and services - with sometimes frustrating and bewildering results. While DRM in the pay-per-download market for music has been too inconvenient to succeed, it is today so tightly integrated into many services we use daily that we barely recognized them (e.g. streaming). Upload filtering technologies combined with IP rights databases such as YouTube's ContentID similarly constitute ordering processes on the technological layer. Algorithms sift through every uploaded video and identify audio snippets that match items in their IP database. As a default, every match is a potential copyright infringement, notwithstanding possible fair use practices and other restrictions of copyright claims. In effect, these systems tend to overblock content by removing works that are not infringing at all.

Turning to the case of imitation and innovation in games production, this dimension addresses the technological infrastructure of game development. Programmers and graphic artists routinely use software and programming environment that provides huge libraries and modules helping to build the game. No new game is technically built from scratch. In effect, the specific degree of imitation and innovation is strongly dependent on the technologies and their affordances. Level-design, game engine, as well as the control of the game character are regularly adopted from existing games, not only the concepts but also the implementation.

In sum, the technological layer is one dimension where the governance of creative production and consumption is situated. Like other institutional elements, it does not determine practices, but enables, constrains, and nudges people into one direction and rather hides alternatives.

\section{A MODEl For COMPARATIVE COPYRIGHT RESEARCH}

\section{A. Comparing Modes of Governance within a Sector}

In analytically distinguishing different modes, discussing their interplay sometimes gets neglected. The key analytical and empirical value of the proposed governance is exactly to investigate the relation between these dimension and their respective effects. The actual relation between laws, norms, discourses and possibly technological affordances in a specific context is an empirical question that is amenable to research.

Turning to our case study on game production, I have already highlighted several differences in the evaluation of game design practices in chapter 
IV. In the following table (see Table 2), I summarise and compare this evaluations across the four dimensions and two practices: re-skinning and retro/hommage games.

\begin{tabular}{|c|c|c|c|c|}
\hline & Regulative & Normative & Discursive & Technology \\
\hline Re-Skinning & No infringement & $\begin{array}{c}\text { Objectionable } \\
\text { Practice }\end{array}$ & $\begin{array}{c}\text { Not considered } \\
\text { creative work }\end{array}$ & $\begin{array}{c}\text { Re-engineer the } \\
\text { product with new } \\
\text { code and ele- } \\
\text { ments }\end{array}$ \\
\hline Hommage/Retro & $\begin{array}{c}\text { Infringing use of } \\
\text { graphics and } \\
\text { sounds }\end{array}$ & $\begin{array}{c}\text { If creative } \\
\text { remake, } \\
\text { then legitimate }\end{array}$ & Creative work & $\begin{array}{c}\text { Re-use of ele- } \\
\text { ments }\end{array}$ \\
\hline
\end{tabular}

Table 2: Comparative Evaluation of Game Design Practices (white box: considered legitimate practice; dark box: considered illegitimate practice)

As mentioned, re-skinning refers to re-producing a (often succesful) game by copying the logic and mechanics of a game and only changing the art style. From a legal perspective, this is in most cases a non-infringing practice. As long as graphics and sounds are substiantially altered, and the software code is re-written, this does not violate copyright or other legal provisions. On the contrary, the normative evaluation within the game design community strongly objects this practice. Looking at re-skinning from the discursive perspective, this is not only considered a normatively objectionable practice, game designers more fundamentally refrain from qualifying this a creative practice in the first place. From a technological perspective, re-skinning is not effortless because all material elements (graphics, sounds, software code) need to be redone, in order not to infringe upon the original.

A contrasting case is the production of hommage or retro games. Popular especially in the context of indepent developers is the production of games that allude to iconic games, oftenly from the 1980ies or 1990ies, such as Super Mario Brothers. Typically game designers take the characters and maybe soundbits from these old games, and produce new games with a different game-play and narrative. From a legal perspective this regularly constitutes copyright infringement, since developers include the original, thus protected characters or very close adaption, they integrate iconical 
graphic elements or soundbits. Yet, from the developer community's normative point of view, this does not violate community norms as long as the game constitutes a creative remake of the original, eg. by performing a gender-swap of the main characters or giving the game a different twist in game play.

These short examples illustrate the analytical and empirical value of this model. Depending on the object of study, the four governance dimensions afford and support different creative and economic practices - and in many cases, they are not congruent. Regulative provisions diverge with normative assumptions in a community, public discourse is at struggle with practices enabled - and maybe even nudged - by new technologies. This is not only the case with game designers as presented. The same is true for the mismatches identified by Jessica Silbey, ${ }^{80}$ and also for the community norms in low IP regimes. Similarly to the game designers, both French chefs and comedians seems to value greatly the underlying idea of their creative work. Thus, the informal ownership claim put forward by creatives in these sectors encompasses game play and mechanics (game designers), the combination and preparation of ingredients (French chefs) and the core structure of a routine and joke (comedians) - elements that are typically not protected by copyright as they are considered ideas rather than works. The analytical framework presented here thus allows us to identify these mismatches and to discuss possible reactions, if necessary.

\section{B. Comparing Modes of Governance across Sectors}

This model also allows copyright and IP scholars to compare modes of governance across sectors. In the discussion of low IP regimes and other sectors we have seen that the impact and salience of different modes of governance varies: In the case of French chef and comedians, for example, informal norms appear as the main governance mode. In game design, norms have emerged as a relevant mode as well, but regulative, discursive and technological aspects also contribute to the ordering of creative practices. In other sectors, copyright legislation and licensing contracts might well determine strongly creative practices and outputs. 


\begin{tabular}{|c|l|l|l|l|}
\hline & Regulative & Normative & Discursive & Technology \\
\hline Sector A & & & & \\
\hline Sector B & & & & \\
\hline Sector C & & & & \\
\hline
\end{tabular}

Table 3: Comparative Assessment of Governance Modes across Sectors (black box: strong impact; grey: average impact; white: weak impact)

The schematized comparison of sectors in Table 3 illustrates the analytical value of the presented governance model. Prevalent copyright research presumes a strong impact of law, ideally incentivizing innovationand then concludes, allegedly with surprise, that "IP is not working as it should" ${ }^{\prime 1}$ or that some sectors represent a "negative space of IP" ${ }^{82}$ This is because copyright researchers tend to focus on law and other legal instruments, but in the context of the presented model this is but one dimension. In consequence, the model allows us to comparetively address the respective impact of different governance modes: regulation, norms, discourses, technology. It turns the assumption of copyright and IP scholarship and policy (that IP (a) has impact on creative practices and (b) incentivizes innovation) into an empirical question: ${ }^{83}$ What is the impact of IP on creative practices in relation to norms, discourses and technology? Does it hinder or promote innovation? And what is considered innovation in the first place? Only by bringing different modes of governance into relation, instead of isolating regulative means, we start to fully understand the interaction between creative practices.

\section{DISCUSSION}

This paper has set out to develop a multimodal concept of copyright governance. In a nutshell, it elaborates the point that there is always more than law in controlling IP - not only in low IP regimes. Building on institu-

81. Silbey, supra note 1 , at 347.

82. Rosenblatt, supra note 7.

83. Cf. Burk, supra note 2, at 452, and Silbey, supra note 42, at 347. 
tional theories, I suggest four modes of copyright governance: (1) A regulative dimension, addressing the provision and enforcement of formal rules such as laws, court decisions, terms of services; (2) a normative dimension, investigating the prevalent assumptions about legitimate and illegitimate behavior in a specific community or sector; (3) a discursive dimension, addressing the framings and debates on creativity, authorship and originality; and (4) a technological dimension that investigates the embodiment of affordances and rules in infrastructures, devices, and algorithms relevant to creative work.

In analytically distinguishing different modes, discussing their interplay sometimes gets neglected. But that is exactly the core idea of this governance model: ordering takes places when these dimensions reinforce each other, but also when they contest each other. Especially in the context of copyright, divergence between these dimensions has been obvious in recent years. Technologies strongly nudge users towards infringing behaviors, norms prevalent in many communities do not fit well the formal IP regulations, etc.

The illustrative case study on imitation and innovation in games production similarly has shown incongruences between the dimensions. Whereas legal regulation allows re-skinning of games, developers consider that as bad and objectionable practice.

The empirical value of this model is that it allows comparative approaches. It allows to compare the empirical impact and specific effects of the respective dimensions within one sector, but also across sectors. From this perspective, the prominent low IP sectors can be characterized by a low level of formal IP regulation but a high level of informal normative expectations. The governance of content on online platforms, such as YouTube or Facebook, constitutes a promising example for future case studies. On the regulative dimension, we might expect a shift from public law to contractual elements such as Terms of Service and Community Guidelines. Similarly, we seem to experience a shift towards regulation on the technological dimension given the massive amount of content that these platforms host and the increasing political pressure for taking accountability for this content. In consequence, the platforms implement filtering mechanisms.

I hope to stimulate the discussion on theoretical aspects of interdisciplinary copyright research with this paper. The literature on low IP regimes has given many impulses for extending our understanding of how creative work is ordered and framed. This paper tries to develop this line of thinking into a coherent framework that integrates diverse modes of ordering - without privileging one over the other. The specific impact of the respective modes is an empirical question. I hope the copyright governance model put forward here can contribute to answering this question. 